\title{
ALTERNATIF INDEKS GIZI SEIMBANG UNTUK PENILAIAN MUTU GIZI KONSUMSI PANGAN PRIA DEWASA INDONESIA
}

(Balanced Diet Indices for the Assessment of Nutritional Quality of the Diet of Indonesian Adult Males)

\author{
Atika Primadala Amrin ${ }^{1 *}$, Hardinsyah², dan Cesilia Meti Dwiriani² \\ 'Department of Regulatory Affairs, Frisian Flag Indonesia, Jl. Raya Bogor Km. 5, Pasar Rebo Jakarta Timur, \\ Jakarta 13760 \\ 2Departemen Gizi Masyarakat, Fakultas Ekologi Manusia (FEMA), Institut Pertanian Bogor, Bogor 16680
}

\begin{abstract}
The study was aimed to develop Balanced Diet Index (BDI) for Indonesian adult males. The spesific purposes of this study were to assess food consumption pattern of Indonesian adult males, to develop several alternatives of BDIs and to select the most appropriate BDI for Indonesian adult males. The design of the study was crosssectional, using the food consumption data from Basic Health Research 2010 collected using 24-hours recall method. The data covered 64448 subjects, and 61129 of them were analyzed in this study. There were 10 alternatives of BDIs developed based on the food group and their intake, and also their scoring systems. The gold standard used to validate the BDI is the mean adequacy ratio (MAR) measured by mean nutrient adequacy of 16 nutrients. The result showed the pearson correlation coefficient of the BDI and MAR range from 0.46 to 0.64. The most appropriate BDI to determine MAR is BDI3-60 ( $r=0.64)$. BDI3-60 consists of six food and implementing 3-level of scoring system.
\end{abstract}

Keywords: adult males, balanced diet index, mean adequacy ratio

\begin{abstract}
ABSTRAK
Penelitian ini bertujuan untuk mengembangkan Indeks Gizi Seimbang (IGS) untuk pria dewasa Indonesia. Tujuan khusus penelitian ini adalah untuk menganalisis pola konsumsi pangan pria dewasa Indonesia berdasarkan data Riskesdas 2010; mengembangkan alternatif IGS untuk pria dewasa Indonesia; menguji validitas dan menentukan IGS terpilih. Penelitian ini menggunakan data Riskesdas 2010. Terdapat 64448 pria dewasa yang diwawancarai dalam Riskesdas 2010, 61129 diantaranya disertakan dalam analisis penelitian ini. Penelitian ini mengembangkan 10 alternatif IGS. Standar yang digunakan untuk validasi IGS adalah nilai mutu gizi pangan (MGP) yang dihitung berdasarkan tingkat kecukupan dari 16 zat gizi. Hasil penelitian menunjukkan nilai koefisien korelasi antara IGS dan MGP berkisar antara 0.46-0.64. IGS yang paling sesuai untuk menilai mutu gizi konsumsi pangan pria dewasa Indonesia adalah IGS3-60. IGS3-60 adalah indeks dengan penilaian tiga tingkat dan terdiri atas enam komponen penilaian yang berupa kelompok pangan.
\end{abstract}

Kata kunci: indeks gizi seimbang, mutu gizi konsumsi pangan, pria dewasa

"Korespondensi: Department of Regulatory Affairs, Frisian Flag Indonesia, Jl. Raya Bogor Km. 5, Pasar Rebo Jakarta Timur, Jakarta 13760. Email: atika.amrin@gmail.com 
Amrin dkk.

\section{PENDAHULUAN}

Kelompok pria dewasa merupakan penduduk dalam rentang usia produktif yang memiliki peranan besar dalam menggerakkan roda pembangunan bangsa. Oleh karena itu, masalah gizi yang terjadi pada kelompok ini tidak dapat diabaikan. Data Riskesdas 2010 menunjukkan kejadian overweight dan obesitas pada pria paling banyak ditemukan pada rentang usia dewasa. Prevalensi overweight dan obesitas pada pria di kelompok umur 25 hingga 50 tahun relatif lebih tinggi daripada pria di kelompok umur remaja maupun lansia. Analisis yang dilakukan berdasarkan data Riskedas 2007 menunjukkan terdapat korelasi antara pertambahan umur dengan kejadian obesitas sentral (Sugianti et al. 2009). Obesitas berkaitan erat dengan kejadian penyakit degeneratif. Peningkatan prevalensi obesitas akan meningkatkan angka kematian yang disebabkan hipertensi dan diabetes (Henry 2011).

Suatu penelitian di Amerika menunjukkan bahwa wanita cenderung memiliki sikap dan perilaku kesehatan yang lebih baik daripada pria, sehingga jumlah pria yang menderita penyakit kardiovaskular lebih banyak dan pria meninggal 7 tahun lebih cepat daripada wanita (Courtenay 2003). Mortalitas akibat penyakit jantung koroner lebih tinggi pada pria dibandingkan wanita (Lawlor et al. 2003). Banyak faktor risiko yang memengaruhi hipertensi, penyakit kardiovaskular, diabetes, kanker, dan penyakit tidak menular lainnya merupakan bagian dari gaya hidup yang dapat dicegah. Gaya hidup yang dimaksud seperti rendahnya tingkat aktivitas fisik, rendahnya konsumsi buah dan sayur, konsumsi makanan cepat saji serta kebiasaan merokok (Khatib 2004).

Salah satu strategi yang dapat dilakukan untuk mengendalikan perkembangan masalah gizi adalah melalui promosi gizi dan kesehatan. Promosi gizi dan kesehatan dapat dilakukan dengan cara menyebarkan informasi perilaku gizi dan kesehatan yang benar, sehingga dapat mendorong perubahan perilaku kesehatan di dalam masyarakat (Khatib 2004). Indonesia telah mengembangkan Pedoman Umum Gizi Seimbang (PUGS) yang berisi 13 pesan untuk menggiring masyarakat agar mengonsumsi makanan dengan prinsip makanan yang bergizi, berimbang, dan beraneka ragam.

Meskipun PUGS telah disosialisasikan sejak tahun 1994, namun instrumen untuk mengukur kualitas konsumsi pangan masyarakat Indonesia berdasarkan standar PUGS belum dikembangkan. Instrumen penilaian kualitas konsumsi pangan yang dimaksud adalah Indeks Gizi Seimbang (Healthy Eating Index/HEI). HEl adalah alat ukur yang pertama kali dikembangkan oleh Center for Nutrition Policy and Promotion USDA, yaitu untuk mengukur kepatuhan konsumsi makanan individu dihubungkan dengan angka kecukupan berdasarkan piramida makanan.
HEI sudah dikembangkan sejak pertengahan tahun 1990 untuk menyediakan suatu kesimpulan pengukuran kualitas konsumsi makanan (Guenther et al. 2008). Selain di Amerika Serikat, negara lain seperti Thailand dan Australia juga telah mengembangkan HEI untuk mengukur kualitas konsumsi makanan di wilayah masing-masing. HEI Amerika pertama kali dikembangkan pada tahun 1995, terdiri atas 10 komponen penilaian yang menilai kesesuaian konsumsi kelompok pangan tertentu, asupan zat gizi serta keragaman jenis pangan yang dikonsumsi. Amerika kemudian melakukan perbaikan HEI pada tahun 2005 sejalan dengan The 2005 Dietary Guidelines for Americans. HEl yang dikembangkan pada tahun 2005 juga terdiri atas 10 komponen penilaian. Perbedaan dengan HEl Amerika yang dikembangkan sebelumnya ada pada jenis kelompok pangan serta cara penilaian yang berdasarkan densitas energi (Guenther et al. 2008).

Pengembangan Indeks Gizi Seimbang (IGS) untuk pria dewasa di Indonesia penting agar kualitas konsumsi makanan secara keseluruhan pada kelompok ini dapat diketahui, serta perubahan pola makan dapat dimonitor. Informasi ini dapat menjadi dasar untuk menentukan strategi perbaikan pola konsumsi makan pada pria dewasa bagian dari upaya mengendalikan penyakit tidak menular (PTM).

Secara umum penelitian ini bertujuan untuk mengembangkan IGS bagi pria dewasa di Indonesia. Tujuan khusus penelitian ini adalah menganalisis pola konsumsi pangan, mengembangkan beberapa alternatif IGS, dan menguji validitas dari berbagai alternatif IGS dan menentukan IGS terpilih pria dewasa di Indonesia.

\section{METODE}

\section{Desain, Tempat, dan Waktu Penelitian}

Penelitian ini menggunakan data sekunder dari Riset Kesehatan Dasar (Riskesdas) yang dikumpulkan pada bulan Mei hingga Agustus 2010 oleh Badan Penelitian dan Pengembangan Kesehatan Kementerian Kesehatan Indonesia. Desain penelitian analitik ini untuk mengembangkan sebuah indeks. Pengolahan, analisis, dan interpretasi data dilakukan pada bulan Juni-Oktober 2013 di Bogor, Jawa Barat.

\section{Jumlah dan Cara Pengambilan Subjek}

Penelitian ini menggunakan data Riskesdas 2010. Riskesdas 2010 berhasil mengunjungi 2798 blok sensus dari 441 kabupaten/kota, jumlah rumah tangga dari blok sensus tersebut sebanyak 69300 rumah tangga dengan jumlah rumah tangga sebanyak 251388 anggota. Jumlah subjek dalam rentang usia dewasa (19-55 tahun) adalah 132934 orang, sebanyak 64448 di antaranya berjenis kelamin pria.

Proses cleaning dilakukan terhadap subjek yang tidak memiliki data antropometri (197 orang) 
dan data asupan pangan (84 orang). Cleaning juga dilakukan pada subjek yang memiliki IMT $<13$ dan IMT $>40$ (74 orang), asupan pangan $<0.3$ atau $>3$ kali energi basal (2013 orang), serta pada subjek dengan tingkat kecukupan zat gizi $>400 \%$ (12 orang). Total subjek dalam penelitian ini adalah 61129 pria dewasa.

\section{Jenis dan Cara Pengumpulan Data}

Data yang digunakan dalam penelitian ini seluruhnya merupakan data sekunder. Data yang digunakan adalah data karakterisitik subjek dan karakteristik sosial ekonomi, data antropometri dan data konsumsi pangan. Pengumpulan data karakteristik subjek dan karakteristik sosial ekonomi dilakukan dengan wawancara. Data antropometri meliputi berat badan dan tinggi badan diperoleh dengan pengukuran langsung oleh enumerator Riskesdas. Data konsumsi pangan diperoleh dengan metode recall 24 jam.

\section{Pengolahan dan Analisis Data}

Pengembangan Indeks Gizi Seimbang. IGS yang dikembangkan dalam penelitian mengacu pada pengembangan indeks serupa di Amerika dan Thailand, serta dimodifikasi sesuai dengan pedoman makan yang ada di Indonesia. Pengembangan IGS pada prinsipnya adalah menentukan komponen penilaian dan cara pemberian nilainya (skoring). Komponen penilaian pada IGS secara umum terbagi dua, yaitu konsumsi kelompok pangan dan konsumsi zat gizi yang terkait dengan penyakit tidak menular. Kelompok pangan dalam IGS adalah kelompok pangan sumber karbohidrat, sayuran, buah-buahan, pangan hewani, dan pangan nabati (kacang-kacangan). Komponen zat gizi yang disertakan dalam IGS antara lain adalah gula tambahan, lemak total, lemak jenuh, kolesterol, dan sodium. Cara penilaian pada indeks juga terbagi atas dua, yaitu penilaian tiga tingkat (IGS3) dan penilaian empat tingkat (IGS4).

Perbedaan alternatif IGS yang dikembangkan dalam penelitian ini terletak pada komponen yang dinilai dan sistem pemberian nilai untuk setiap komponen. Setiap cara penilaian memiliki lima alternatif IGS yang perbedaannya terletak pada jumlah komponen yang menjadi fokus penilaian. Masing-masing IGS3 dan IGS4 memiliki lima alternatif, sehingga terdapat 10 alternatif IGS yang dikembangkan. Tabel 1 menyajikan 10 komponen penilaian dan kriteria penilaian untuk sistem penilaian tiga tingkat.

IGS dengan sistem penilaian tiga tingkat, artinya indeks ini dinilai dengan skor tiga tingkatan, yaitu skor minimal, skor tengah, dan skor maksimal. Contohnya pada indeks dengan 10 komponen, setiap komponennya memiliki rentang skor $0-10$, maka skor minimal adalah nol, skor tengah adalah lima dan skor maksimal adalah 10 untuk setiap komponen. Contoh penilaian empat tingkat pada indeks dengan 10 komponen, yaitu skor minimal adalah nol, skor tingkat dua adalah empat, skor tingkat tiga adalah tujuh dan skor maksimal adalah 10. Seluruh alternatif IGS memiliki nilai total minimal 0 dan maksimal 100. IGS dengan sistem empat tingkat menggunakan skor $0,4,7$, dan 10. Dengan cara yang sama seperti tiga tingkat, digunakan 10 komponen dan kriteria penilaian.

Setiap alternatif IGS dinamakan sesuai dengan kategori penilaian, jumlah seluruh komponen

Tabel 1. Komponen dan Kriteria Penilaian Indeks Gizi Seimbang Tiga Tingkat

\begin{tabular}{|c|c|c|c|}
\hline \multirow{2}{*}{ Komponen } & \multicolumn{3}{|c|}{ Skor } \\
\hline & 0 & 5 & 10 \\
\hline Konsumsi Pangan Karbohidrat & $<4$ porsi & 4-8 porsi & $\geq 8$ porsi \\
\hline Konsumsi Sayuran & $<1$ porsi & $1-3$ porsi & $\geq 3$ porsi \\
\hline Konsumsi Buah & $<1 / 2$ porsi & $1 / 2-2$ porsi & $\geq 2$ porsi \\
\hline Konsumsi Lauk Hewani (Total) & $<1 \frac{1}{4}$ porsi & $1 \frac{1}{4}-4$ porsi & $\geq 4$ porsi \\
\hline Lauk Hewani (selain susu) & $<1$ porsi & $1-3$ porsi & $\geq 3$ porsi \\
\hline Susu & $<1 / 4$ porsi & $1 / 4-1$ porsi & $\geq 1$ porsi \\
\hline Konsumsi Lauk Nabati & $<1$ porsi & $1-3$ porsi & $\geq 3$ porsi \\
\hline Asupan Lemak Total & $>30 \%$-e atau $<10 \%$-e & $20-30 \%-e$ & $10-20 \%-e$ \\
\hline Asupan Lemak Jenuh & $>10 \%$-e atau $<2 \%$-e & $6-10 \%-e$ & $2-6 \%-e$ \\
\hline Konsumsi Gula Tambahan & $>20 \%-e$ & $5-20 \%-e$ & $\leq 5 \%-e$ \\
\hline Asupan Kolesterol & $>300 \mathrm{mg}$ atau <100 mg & $200-300 \mathrm{mg}$ & $100-200 \mathrm{mg}$ \\
\hline Asupan Sodium & $>2000 \mathrm{mg}$ atau $<500 \mathrm{mg}$ & $1000-2000 \mathrm{mg}$ & $500-1500 \mathrm{mg}$ \\
\hline
\end{tabular}

Keterangan:

1 porsi KH setara $100 \mathrm{~g}$ nasi

1 porsi sayur setara $100 \mathrm{~g}$ sayur

1 porsi buah setara $100 \mathrm{~g}$ buah 1 porsi lauk nabati
$10 \%$-e artinya sama dengan $10 \%$ dari kebutuhan energi total.
1 porsi LH (selain susu) setara $50 \mathrm{~g}$ daging

1 porsi susu: $200 \mathrm{ml}$ susu cair/30 g tepung susu

1 porsi lauk nabati setara $50 \mathrm{~g}$ tempe

kebutuhan energi total. 
Amrin dkk.

yang dinilai dan jumlah komponen zat gizi yang disertakan. Contohnya penamaan IGS3-105, artinya alternatif IGS ini dinilai dengan tiga tingkat, terdiri atas 10 komponen penilaian dan lima di antaranya berupa zat gizi terkait penyakit tidak menular (PTM). Sepuluh alternatif IGS yang dikembangkan dalam penelitian ini adalah IGS3-50; IGS3-60; IGS361; IGS3-83; IGS3-105; IGS4-50; IGS4-60; IGS4-61; IGS4-83; IGS4-105. Validasi terhadap alternatif IGS dilakukan dengan melakukan uji korelasi Pearson antara berbagai alternatif indeks dengan nilai Mutu Gizi Pangan (MGP).

Mutu gizi pangan. Mutu gizi pangan dihitung berdasarkan rata-rata tingkat kecukupan energi dan zat gizi lainnya. Nilai tingkat kecukupan zat gizi maksimal adalah 100 (truncated at 100) untuk mencegah terjadinya kompensasi antar nilai tingkat kecukupan zat gizi (Gibson 1995). Terdapat 16 zat gizi yang disertakan dalam perhitungan MGP pada penelitian ini, yaitu energi, protein, lemak, karbohidrat, serat, air, vitamin A, vitamin B1, vitamin B2, vitamin $C$, natrium, kalsium, zat besi, fosfor, kalium, dan seng.

\section{HASIL DAN PEMBAHASAN}

\section{Pola Konsumsi Pangan Pria Dewasa Indonesia}

Konsumsi pangan pria dewasa Indonesia dibedakan ke dalam beberapa kelompok pangan, yaitu pangan sumber karbohidrat, sayuran, buah, lauk he- wani, dan lauk nabati. Tabel 2 menyajikan gambaran konsumsi pangan pria dewasa Indonesia dalam bentuk rataan konsumsi (g), standar deviasi dan median, serta data jumlah subjek yang mengonsumsi (\%) pada setiap kelompok pangan.

Rata-rata konsumsi pangan sumber karbohidrat berkisar antara $596 \mathrm{~g}$ hingga $612.4 \mathrm{~g}$. Jumlah subjek yang mengonsumsi pangan sumber karbohidrat adalah yang tertinggi bila dibandingkan dengan kelompok pangan lainnya, yaitu sebesar $99.9 \%$. Jumlah konsumsi pangan sumber karbohidrat yang ada pada kisaran 600 g setara dengan enam porsi dan sudah mendekati anjuran konsumsi untuk pria dewasa, yaitu sebanyak delapan porsi per hari. Faktor-faktor yang dapat memengaruhi konsumsi pangan sumber karbohidrat baik di Indonesia antara lain adalah faktor ekologi yang meliputi ketersediaan pangan, pendapatan, dan tingkat pendidikan subjek (Apriani \& Baliwati 2011).

Secara keseluruhan rata-rata subjek mengonsumsi $99.1 \mathrm{~g}$ sayuran, dengan jumlah subjek yang mengonsumsi sebesar $67 \%$. Lebih banyak subjek yang mengonsumsi sayuran dibandingkan buah-buahan, hanya $26.6 \%$ subjek mengonsumsi buah-buahan dengan rata-rata $41.7 \mathrm{~g}$ buah sehari. Konsumsi sayuran dan buah-buahan masih belum memenuhi standar yang dianjurkan bagi orang dewasa berdasarkan studi yang telah dilakukan oleh Nurhayati (2013), yaitu sebanyak $300 \mathrm{~g}$ untuk sayuran dan $200 \mathrm{~g}$ untuk buah-buahan. Demikian pula dengan standar yang

Tabel 2. Rataan, Standar Deviasi, Median Konsumsi (g) dan Tingkat Partisipasi Konsumsi Kelompok Pangan pada Pria Dewasa Indonesia

\begin{tabular}{|c|c|c|c|c|}
\hline \multirow{4}{*}{ Kelompok Pangan } & \multicolumn{3}{|c|}{ Umur (Tahun) } & \multirow{2}{*}{ Total } \\
\hline & $19-29$ & $30-49$ & $50-55$ & \\
\hline & Mean \pm SD & Mean \pm SD & Mean \pm SD & Mean \pm SD \\
\hline & (med)\% & (med)\% & (med)\% & (med)\% \\
\hline \multirow{2}{*}{ Pangan Karbohidrat } & $606.5 \pm 225.0$ & $612.4 \pm 229.1$ & $596.2 \pm 228.6$ & $608.5 \pm 227.8$ \\
\hline & $(600.0) 99.9 \%$ & (600)99.9\% & $(600) 99.9 \%$ & $(600) 99.9 \%$ \\
\hline \multirow{2}{*}{ Sayuran } & $90.9 \pm 112.7$ & $102.3 \pm 121.5$ & $105.2 \pm 124.4$ & $99.1 \pm 119.3$ \\
\hline & $(60.0) 64.7 \%$ & $(75) 68.2 \%$ & $(80) 67.3 \%$ & $(75) 67 \%$ \\
\hline \multirow{2}{*}{ Buah } & $38.2 \pm 95.4$ & $42.9 \pm 99.4$ & $45.2 \pm 101.9$ & $41.7 \pm 98.5$ \\
\hline & $(0.0) 24.4 \%$ & $(0.0) 27.4 \%$ & $(0.0) 28.8 \%$ & $(0.0) 26.6 \%$ \\
\hline \multirow{2}{*}{ Lauk Hewani (total) } & $117.2 \pm 104.4$ & $117.2 \pm 107.6$ & $107.8 \pm 106.1$ & $116.1 \pm 107.6$ \\
\hline & $(100.0) 81.1 \%$ & $(100) 80.2 \%$ & (90)77.1\% & (100)80.1\% \\
\hline \multirow{2}{*}{$\begin{array}{l}\text { Lauk Hewani } \\
\text { (selain susu) }\end{array}$} & $114.0 \pm 104.4$ & $114.9 \pm 105.2$ & $105.6 \pm 103.5$ & $113.5 \pm 104.8$ \\
\hline & $(100) 80.6 \%$ & $(100) 79.8 \%$ & $(90) 76.6 \%$ & (100)79.7\% \\
\hline \multirow{2}{*}{ Susu } & $3.2 \pm 85.4$ & $2.2 \pm 19.4$ & $2.3 \pm 19.2$ & $2.5 \pm 21.5$ \\
\hline & $(0.0) 0.05 \%$ & $(0.0) 0.04 \%$ & $(0.0) 0.04 \%$ & $(0.0) 0.04 \%$ \\
\hline \multirow{2}{*}{ Lauk Nabati } & $53.6 \pm 85.4$ & $58.2 \pm 89.9$ & $62.8 \pm 92.6$ & $57.3 \pm 88.9$ \\
\hline & $(0.0) 45.7 \%$ & $(0.0) 47.1 \%$ & $(0.0) 48.7 \%$ & $(0.0) 46.9 \%$ \\
\hline \multirow{2}{*}{ Gula Tambahan } & $3.6 \pm 15.1$ & $4.9 \pm 16.3$ & $5.1 \pm 16.8$ & $4.5 \pm 15.9$ \\
\hline & $(0.0) 4.1 \%$ & $(0.0) 10.1 \%$ & $(0.0) 2.3 \%$ & $(0.0) 17.6 \%$ \\
\hline
\end{tabular}


telah ditetapkan oleh WHO yaitu sebanyak $400 \mathrm{~g}$ masing-masing untuk sayuran dan buah-buahan juga tidak terpenuhi.

Konsumsi sayuran dan buah-buahan memiliki efek protektif terhadap kejadian berbagai macam jenis kanker, seperti kanker di saluran pencernaan, kanker paru-paru serta kanker payudara (Riboli \& Norat 2003). Konsumsi sayuran dan buah-buahan juga berkontribusi dalam menurunkan risiko kejadian penyakit jantung koroner (He et al. 2007). Meningkatkan konsumsi sayuran dan buah-buahan telah terbukti dapat menurunkan risiko penyakit tidak menular atau penyakit degeneratif. Oleh karena itu penting untuk menekankan peningkatan konsumsi sayuran dan buah-buahan pada kebijakan kesehatan masyarakat di setiap negara untuk mencegah perkembangan PTM atau penyakit degeneratif (Lock et al. 2005).

Pria dewasa Indonesia mengonsumsi rata-rata $116.1 \mathrm{~g}$ pangan lauk hewani termasuk dengan susu. Namun apabila susu dipisahkan dari pangan hewani, maka subjek mengonsumsi susu sebanyak rata-rata $2.5 \mathrm{~g}$. Tingkat partisipasi konsumsi susu seluruh subjek hanya $0.04 \%$. Susu merupakan salah satu jenis pangan hewani dengan kandungan kalsium yang tinggi. Suatu penelitian menunjukkan bahwa frekuensi konsumsi susu berhubungan dengan berat badan dan kepadatan tulang (Hardinsyah et al. 2008)

Tabel 3. menyajikan data asupan dan tingkat kecukupan gizi subjek. Berdasarkan data konsumsi masing-masing subjek, dapat diketahui asupan dan tingkat kecukupan gizi yang subjek (\%). Tingkat kecukupan gizi menunjukkan sejauh mana makanan yang dikonsumsi dapat memenuhi kebutuhan zat gizi subjek. Konsumsi subjek telah memenuhi 52.5\% kebutuhan energi dalam sehari. Kebutuhan protein terpenuhi sebesar $68.8 \%$ dan kebutuhan lemak terpenuhi sebesar 54.1\%. Apabila persentase tingkat kecukupan gizi makro subjek dibandingkan dengan standar, maka rata-rata subjek tergolong defisit tingkat berat karena pemenuhan gizi makro masih kurang dari $70 \%$ kebutuhan gizi sehari. Data konsumsi dikumpulkan dengan metode recall 24 jam, dimana informasi tersebut hanya mengandalkan ingatan subjek tentang konsumsi sehari sebelumnya, sehingga dapat terjadi subjek lupa menyebutkan seluruh jenis maupun jumlah pangan yang dikonsumsi secara akurat. Bias pada data konsumsi juga dapat terjadi pada konversi satuan ukuran rumah tangga (URT) ke dalam satuan berat (g), hal ini karena terdapat perbedaan pada setiap daerah mengenai makna ukuran makanan seperti potong, iris, bungkus, batang dan ikat serta perbedaan pada alat makan yang menjadi ukuran makanan dalam rumah tangga (Handayati et al. 2008).

Konsumsi makanan subjek telah cukup memenuhi kebutuhan natrium (172.5\%) dan kebutuhan fosfor (94.1\%) dalam sehari, namun masih belum mencukupi kebutuhan kalsium (31.2\%); besi (39.9\%); dan kalium (19.6\%). Demikian pula dengan vitamin, konsumsi makanan subjek dalam sehari telah mencukupi kebutuhan vitamin B1 (316.5\%) dan vitamin B2 $(211.8 \%)$, namun belum dapat mencukupi kebutuhan vitamin A (29.3\%) dan vitamin C (10.8\%). Kebutuhan vitamin dan mineral dikatakan cukup terpenuhi apabila tingkat kecukupannya lebih dari $65 \%$.

Tingginya asupan vitamin B1 dapat dikaitkan dengan tingginya konsumsi pangan sumber karbohidrat pada subjek. Pangan sumber karbohidrat utama yang dikonsumsi subjek berupa nasi, karena nasi merupakan pangan pokok masyarakat di Indonesia. Nasi atau beras merupakan kelompok serealia yang kaya akan vitamin B. Sedangkan rendahnya tingkat kecukupan vitamin $C$ maupun vitamin $A$ dapat dikaitkan dengan rendahnya konsumsi sayuran dan buah-buahan. Sayuran dan buah-buahan merupakan sumber serat, vitamin dan mineral.

\section{Alternatif Indeks Gizi Seimbang}

Terdapat 10 alternatif IGS yang dikembangkan dalam penelitian ini. Setiap alternatif IGS dikorelasikan dengan mutu gizi seimbang (MGP) untuk melihat alternatif terbaik. MGP dihitung berdasarkan rata-rata tingkat kecukupan energi dan zat gizi lainnya.

Uji korelasi dengan MGP menunjukkan bahwa IGS3-60 memiliki nilai korelasi tertinggi yaitu sebesar 0.64, sehingga Indeks Gizi Seimbang IGS3-60 merupakan alternatif yang lebih baik bila dibandingkan dengan IGS lainnya untuk menilai mutu gizi konsumsi pangan pria dewasa Indonesia. Sementara indeks lainnya berkisar antara $0.53-0.63$. Hubungan signifikan antara IGS3-60 dengan MGP ( $<<0.01)$, artinya IGS3-60 dapat mencerminkan mutu gizi konsumsi pangan pria dewasa Indonesia. Salah satu studi di Thailand yang mengembangkan instrumen serupa IGS, yaitu THEI (Thailand Healthy Eating Index), menunjukkan terdapat hubungan yang signifikan antara total nilai THEI dan asupan zat gizi $(\mathrm{k}=0.3-$ $0.5, p<0.01)$. Nilai total THEI dapat menggambarkan asupan lemak, lemak jenuh, kolesterol, natrium, dan gula (Taechangam et al. 2008). Meskipun memiliki nilai koefisien korelasi tertinggi dibandingkan alternatif lainnya, IGS3-60 hanya mencakup penilaian terhadap enam komponen saja. Jika turut mempertimbangkan penilaian yang lebih lengkap dan menyeluruh, maka IGS4-105 dapat menjadi alternatif indeks untuk menilai mutu gizi konsumsi pangan pria dewasa Indonesia.

Studi yang dilakukan oleh Anwar (2013) mengenai hubungan antara pola pangan harapan (PPH) dengan MGP pada kelompok orang dewasa Indonesia menunjukkan nilai korelasi antar PPH dan MGP sebesar 0.72. Terlihat bahwa jika dihubungkan dengan nilai MGP nilai korelasi antara PPH maupun IGS3- 
Amrin dkk.

Tabel 3. Asupan dan Tingkat Kecukupan Gizi Sehari Pria Dewasa Indonesia

\begin{tabular}{|c|c|c|c|c|}
\hline \multirow{3}{*}{ Zat Gizi } & \multicolumn{3}{|c|}{ Umur (Tahun) } & \multirow{2}{*}{ Total } \\
\hline & $19-29$ & $30-49$ & $50-55$ & \\
\hline & $\begin{array}{l}\text { Mean } \pm \text { SD } \\
\left(\% K_{ \pm} \text {SD) }\right.\end{array}$ & $\begin{array}{l}\text { Mean } \pm \text { SD } \\
\left(\% K_{ \pm} \text {SD) }\right.\end{array}$ & $\begin{array}{l}\text { Mean } \pm \text { SD } \\
\left(\% K_{ \pm} \text {SD) }\right.\end{array}$ & $\begin{array}{l}\text { Mean } \pm \text { SD } \\
\left(\% K_{ \pm} \text {SD) }\right.\end{array}$ \\
\hline Energi (kkal) & $\begin{array}{c}1448 \pm 512 \\
(50.8 \pm 19.0)\end{array}$ & $\begin{array}{c}1491 \pm 526 \\
(52.9 \pm 20.1)\end{array}$ & $\begin{array}{c}1471 \pm 518 \\
(54.6 \pm 20.5)\end{array}$ & $\begin{array}{c}1475 \pm 521 \\
(52.5 \pm 19.8)\end{array}$ \\
\hline Protein (g) & $\begin{array}{c}43.1 \pm 23.1 \\
(69.9 \pm 38.6)\end{array}$ & $\begin{array}{l}44.3 \pm 23.6 \\
(68.3 \pm 38 .)\end{array}$ & $\begin{array}{c}43.3 \pm 23.2 \\
(68.3 \pm 38.1)\end{array}$ & $\begin{array}{c}43.8 \pm 23.4 \\
(68.8 \pm 38.3)\end{array}$ \\
\hline Lemak total (g) & $\begin{array}{c}43.7 \pm 22.2 \\
(46.1 \pm 24.2)\end{array}$ & $\begin{array}{c}44.9 \pm 22.9 \\
(57.6 \pm 30.6)\end{array}$ & $\begin{array}{c}44.2 \pm 22.2 \\
(59.1 \pm 30.8)\end{array}$ & $\begin{array}{c}44.5 \pm 22.6 \\
(54.1 \pm 29.3)\end{array}$ \\
\hline Lemak jenuh (g) & $\begin{array}{c}13.4 \pm 9.9 \\
(52.9 \pm 39.9)\end{array}$ & $\begin{array}{c}13.9 \pm 10.2 \\
(55.6 \pm 41.8)\end{array}$ & $\begin{array}{c}13.5 \pm 9.8 \\
(56.3 \pm 41.8)\end{array}$ & $\begin{array}{c}13.7 \pm 10.1 \\
(54.8 \pm 41.2)\end{array}$ \\
\hline Kolesterol (mg) & $\begin{array}{l}131.5 \pm 96.3 \\
(43.8 \pm 32.1)\end{array}$ & $\begin{array}{l}129.5 \pm 95.7 \\
(43.2 \pm 31.9)\end{array}$ & $\begin{array}{l}119.7 \pm 88.0 \\
(39.9 \pm 29.3)\end{array}$ & $\begin{array}{l}128.9 \pm 95.1 \\
(42.9 \pm 31.7)\end{array}$ \\
\hline Karbohidrat (g) & $\begin{array}{l}211.8 \pm 80.7 \\
(48.6 \pm 19.5)\end{array}$ & $\begin{array}{l}217.9 \pm 83.2 \\
(47.2 \pm 19.4)\end{array}$ & $\begin{array}{l}215.5 \pm 83.3 \\
(48.9 \pm 20.2)\end{array}$ & $\begin{array}{l}215.7 \pm 82.4 \\
(47.9 \pm 19.5)\end{array}$ \\
\hline Serat $(\mathrm{g})$ & $\begin{array}{c}14.9 \pm 6.8 \\
(37.2 \pm 17.7)\end{array}$ & $\begin{array}{c}15.5 \pm 7.1 \\
(39.2 \pm 18.5)\end{array}$ & $\begin{array}{c}15.5 \pm 7.2 \\
(41.1 \pm 19.5)\end{array}$ & $\begin{array}{c}15.3 \pm 7.0 \\
(38.8 \pm 18.4)\end{array}$ \\
\hline Air $(g)$ & $\begin{array}{c}672.2 \pm 256.8 \\
(26.9 \pm 10.3)\end{array}$ & $\begin{array}{c}693.4 \pm 266.6 \\
(26.7 \pm 10.2)\end{array}$ & $\begin{array}{c}684.3 \pm 267.4 \\
(26.3 \pm 10.3)\end{array}$ & $\begin{array}{c}685.6 \pm 263.8 \\
(26.7 \pm 10.3)\end{array}$ \\
\hline Natrium (mg) & $\begin{array}{c}3349.1 \pm 2559.3 \\
(167.4 \pm 127.9)\end{array}$ & $\begin{array}{c}3485.3 \pm 2666.6 \\
(174.3 \pm 133.3)\end{array}$ & $\begin{array}{c}3552.3 \pm 2861.3 \\
(177.6 \pm 143.1)\end{array}$ & $\begin{array}{c}3450.3 \pm 2658.7 \\
(172.5 \pm 132.9)\end{array}$ \\
\hline Kalsium (mg) & $\begin{array}{c}309.6 \pm 288.8 \\
(28.1 \pm 26.3)\end{array}$ & $\begin{array}{c}326.1 \pm 304.6 \\
(32.6 \pm 30.5)\end{array}$ & $\begin{array}{c}330.2 \pm 295.1 \\
(33.0 \pm 29.5)\end{array}$ & $\begin{array}{c}321.4 \pm 298.6 \\
(31.2 \pm 29.2)\end{array}$ \\
\hline Zat besi (mg) & $\begin{array}{c}4.9 \pm 6.7 \\
(38.1 \pm 51.6)\end{array}$ & $\begin{array}{c}5.3 \pm 7.2 \\
(40.7 \pm 55.4)\end{array}$ & $\begin{array}{c}5.4 \pm 6.8 \\
(41.4 \pm 52.7)\end{array}$ & $\begin{array}{c}5.2 \pm 7.0 \\
(39.9 \pm 53.9)\end{array}$ \\
\hline Fosfor (mg) & $\begin{array}{c}636.3 \pm 425.6 \\
(90.9 \pm 60.8)\end{array}$ & $\begin{array}{c}668.4 \pm 454.4 \\
(95.5 \pm 64.9)\end{array}$ & $\begin{array}{c}669 \pm 457.7 \\
(95.6 \pm 65.4)\end{array}$ & $\begin{array}{c}658.3 \pm 446.2 \\
(94.1 \pm 63.7)\end{array}$ \\
\hline Kalium (mg) & $\begin{array}{c}892.5 \pm 660.6 \\
(18.9 \pm 14.1)\end{array}$ & $\begin{array}{c}938.3 \pm 690.2 \\
(19.9 \pm 14.7)\end{array}$ & $\begin{array}{c}918.7 \pm 690.1 \\
(19.6 \pm 14.7)\end{array}$ & $\begin{array}{c}921.4 \pm 681.3 \\
(19.6 \pm 14.5)\end{array}$ \\
\hline Vitamin A (mcg) & $\begin{array}{c}170.5 \pm 397.2 \\
(28.4 \pm 66.2)\end{array}$ & $\begin{array}{c}180.11 \pm 409.9 \\
(30.0 \pm 68.3)\end{array}$ & $\begin{array}{c}169.5 \pm 376.2 \\
(28.3 \pm 62.7)\end{array}$ & $\begin{array}{c}175.8 \pm 401.9 \\
(29.3 \pm 66.9)\end{array}$ \\
\hline Vitamin B1 (mg) & $\begin{array}{c}3.9 \pm 6.2 \\
(284.4 \pm 447.6)\end{array}$ & $\begin{array}{c}4.3 \pm 6.5 \\
(327.9 \pm 501.4)\end{array}$ & $\begin{array}{c}4.2 \pm 6.6 \\
(347.2 \pm 550.2)\end{array}$ & $\begin{array}{c}4.2 \pm 6.4 \\
(316.5 \pm 491.9)\end{array}$ \\
\hline Vitamin B2 (mg) & $\begin{array}{c}3.2 \pm 5.8 \\
(198.4 \pm 359.3)\end{array}$ & $\begin{array}{c}3.4 \pm 6.1 \\
(212.2 \pm 377.9)\end{array}$ & $\begin{array}{c}3.4 \pm 6.2 \\
(244.22 \pm 442.5)\end{array}$ & $\begin{array}{c}3.3 \pm 5.9 \\
(211.8 \pm 380.9)\end{array}$ \\
\hline Vitamin C (mg) & $\begin{array}{c}9.2 \pm 18 \\
(10.2 \pm 20)\end{array}$ & $\begin{array}{c}9.9 \pm 20.6 \\
(11.1 \pm 22.8)\end{array}$ & $\begin{array}{c}10.3 \pm 23.1 \\
(11.5 \pm 25.7)\end{array}$ & $\begin{array}{c}9.8 \pm 20.1 \\
(10.8 \pm 22.4)\end{array}$ \\
\hline
\end{tabular}

60 tidak berbeda jauh, baik PPH dan IGS3-60 dapat mencerminkan mutu gizi konsumsi pangan. IGS3-60 memiliki keunggulan yaitu lebih sederhana penggunaannya sehingga memudahkan penilaian kualitas konsumsi pangan pria dewasa. Penggunaan IGS3-60 cukup dengan menghitung porsi makan kelompok pangan tertentu dan tidak harus menghitung kandungan zat gizi yang dikonsumsi, sedangkan penggunaan PPH didasarkan pada jumlah asupan energi dari masing-masing kelompok pangan. Namun cara perhitungan MGP pada kedua studi ini berbeda. Studi Anwar (2013) menggunakan 10 zat gizi, sedangkan MGP pada studi ini menyertakan 16 zat gizi. Zat gizi yang berbeda antara lain adalah vitamin B2, kalium, natrium, serat dan air. Tabel 4 menyajikan komponen dan kriteria penilaian IGS3-60.

Indeks serupa yang dikembangkan di Amerika dan Thailand, secara umum terdiri atas 10 hingga 
Tabel 4. Indeks Gizi Seimbang IGS3-60 bagi Pria Dewasa Indonesia

\begin{tabular}{lccc}
\hline \multirow{2}{*}{ Komponen } & \multicolumn{3}{c}{ Skor } \\
\cline { 2 - 4 } & $\mathbf{0}$ & $\mathbf{8 . 3 5}$ & $\mathbf{1 6 . 7}$ \\
\hline Konsumsi Pangan Karbohidrat & $<4$ porsi & $4-8$ porsi & $\geq 8$ porsi \\
Konsumsi Sayuran & $<1$ porsi & $1-3$ porsi & $\geq 3$ porsi \\
Konsumsi Buah-buahan & $<1 / 2$ porsi & $1 / 2-2$ porsi & $\geq 2$ porsi \\
Konsumsi Lauk Hewani & $<1$ porsi & $1-3$ porsi & $\geq 3$ porsi \\
Konsumsi Lauk Nabati & $<1$ porsi & $1-3$ porsi & $\geq 3$ porsi \\
Konsumsi Susu & $\leq 1 / 4$ porsi & $1 / 4-1$ porsi & $\geq 1$ porsi \\
\hline
\end{tabular}

Tabel 5. Skor Indeks Gizi Seimbang IGS3-60

\begin{tabular}{|c|c|c|c|c|}
\hline \multirow{3}{*}{ Komponen } & \multicolumn{3}{|c|}{ Umur (Tahun) } & \multirow{2}{*}{ Total } \\
\hline & $19-29$ & $30-49$ & $50-55$ & \\
\hline & Mean \pm SD $($ Med) & Mean \pm SD $($ Med) & Mean $\pm S D($ Med) & Mean \pm SD $($ Med $)$ \\
\hline Konsumsi Pangan Karbohidrat & $7.5 \pm 5.1(8.4)$ & $7.7 \pm 5.1(8.4)$ & $7.4 \pm 5.2(8.4)$ & $7.6 \pm 5.1(8.4)$ \\
\hline Konsumsi Sayuran & $4.9 \pm 6.4(0.0)$ & $5.4 \pm 6.5(0.0)$ & $5.5 \pm 6.6(0.0)$ & $5.3 \pm 6.5(0.0)$ \\
\hline Konsumsi Buah-buahan & $2.4 \pm 5.2(0.0)$ & $2.8 \pm 5.5(0.0)$ & $2.9 \pm 5.6(0.0)$ & $2.7 \pm 5.4(0.0)$ \\
\hline Konsumsi Pangan Hewani & $6.9 \pm 6.2(8.4)$ & $7.1 \pm 6.3(8.4)$ & $6.7 \pm 6.3(8.4)$ & $6.9 \pm 6.3(8.4)$ \\
\hline Konsumsi Pangan Nabati & $4.4 \pm 6.2(0.0)$ & $4.8 \pm 6.4(0.0)$ & $5.1 \pm 6.5(0.0)$ & $4.7 \pm 6.3(0.0)$ \\
\hline Konsumsi Susu & $0.7 \pm 3.1(0.0)$ & $0.5 \pm 2.6(0.0)$ & $0.5 \pm 2.7(0.0)$ & $0.6 \pm 2.8(0.0)$ \\
\hline Total & $26.8 \pm 12.8(25.1)$ & $28.2 \pm 12.0(25.1)$ & $28.1 \pm 12.9(25.1)$ & $27.8 \pm 12.9(25.1)$ \\
\hline
\end{tabular}

11 komponen penilaian dan cara pemberian nilai dilakukan secara proporsional. Artinya jika konsumsi pangan telah memenuhi anjuran akan diberikan nilai maksimal, apabila konsumsi pangan sama sekali tidak ada maka diberi skor minimal, dan apabila konsumsi pangan berada di antaranya maka pemberian nilai dilakukan secara proporsional. Alternatif IGS yang dikembangkan untuk pria dewasa Indonesia, telah mencakup pemberian nilai secara proporsional, secara tiga tingkat maupun secara empat tingkat. Demikian pula dengan jumlah komponen penilaian, telah mencakup antara 10 komponen hingga lima komponen penilaian saja. Namun demikian, hasil uji korelasi menunjukkan IGS3-60 dengan nilai koefisien korelasi tertinggi untuk menduga mutu gizi konsumsi pangan pria dewasa Indonesia. Indeks Gizi Seimbang IGS3-60 terdiri atas enam komponen penilaian, seluruhnya merupakan penilaian terhadap kesesuaian konsumsi kelompok pangan terhadap standar pedoman makan. Sistem penilaian yang digunakan adalah tiga tingkat.

Tabel 5 menyajikan sebaran nilai IGS3-60 subjek. Setiap komponen memiliki nilai 0-16.7, sehingga jika dijumlahkan nilai dari enam komponen akan diperoleh nilai total yang berkisar antara 0-100. Secara keseluruhan rata-rata subjek masih memiliki nilai yang rendah untuk setiap komponen penilaian konsumsi pangan. Nilai yang paling tinggi ada pada komponen konsumsi pangan karbohidrat yaitu 7.6, hampir mendekati separuh dari nilai maksimal. Konsumsi pangan sumber karbohidrat memiliki nilai yang paling tinggi jika dibandingkan dengan penilaian kelompok pangan lainnya. Hal ini sejalan dengan data konsumsi pangan pada uraian sebelumnya, rata-rata subjek mengonsumsi lebih dari 600 g pangan sumber karbohidrat atau setara dengan enam porsi. Konsumsi pangan sumber karbohidrat sebanyak enam porsi sudah mendekati anjuran pedoman makan (PUGS) untuk konsumsi pria dewasa, yaitu sebanyak delapan porsi dalam sehari

Nilai paling rendah ada pada penilaian konsumsi kelompok susu dan buah-buahan, artinya konsumsi susu dan buah-buahan paling tidak sesuai dengan anjuran pedoman makan. Nilai pada komponen konsumsi sayuran dan pangan lauk nabati juga rendah. Rendahnya nilai yang diperoleh pada penilaian konsumsi sayur dan buah dapat menjelaskan tingkat kecukupan serat dan vitamin yang tidak terpenuhi, seperti vitamin A dan vitamin C (Tabel 3).

Secara total rata-rata nilai IGS3-60 adalah 27.8, atau hanya seperempat dari nilai maksimal yang dapat diperoleh setiap subjek. Hal ini menunjukkan mutu gizi konsumsi pangan pria Indonesia pada tahun 2010 masih buruk dan jauh dari standar yang dianjurkan oleh pedoman PUGS. Senada dengan penelitian yang dilakukan di Thailand yang menilai kualitas konsumsi pangan pada 121 orang pekerja dewasa menggunakan THEI. Sebesar 69\% subjek penelitian memiliki nilai THEl dibawah 55, artinya masih banyak subjek dengan mutu konsumsi pangan buruk (Taechangam et al. 2008). Rendahnya mutu konsumsi pangan subjek di Indonesia paling utama disebabkan rendahnya konsumsi susu, pangan nabati, sayuran, dan buah-buahan (Tabel 4). 
Amrin dkk.

\section{KESIMPULAN}

Seluruh subjek mengonsumsi pangan sumber karbohidrat, namun jumlah subjek yang mengonsumsi buah, sayur, pangan nabati, dan susu masih sangat rendah. Konsumsi makanan sehari subjek belum dapat memenuhi kebutuhan gizi sehari, terlihat dari tingkat kecukupan gizi makro yang tergolong defisit berat, dan masih terdapat kebutuhan vitamin dan mineral yang belum tercukupi. Terdapat 10 alternatif IGS yang dikembangkan. Berdasarkan hasil uji korelasi terhadap MGP, Indeks Gizi Seimbang IGS360 dengan nilai korelasi tertinggi $(r=0.64)$. IGS3-60 merupakan indeks yang lebih baik dibandingkan alternatif IGS lain untuk menilai mutu gizi konsumsi pangan pria dewasa Indonesia. Namun jika ingin mempertimbangkan penilaian yang lebih lengkap dan menyeluruh, dapat menggunakan IGS4-105.

IGS3-60 merupakan metode praktis yang dapat digunakan untuk menilai kualitas konsumsi pangan pria Indonesia, karena penggunaan IGS3-60 hanya didasarkan pada jumlah konsumsi pangan harian. Studi lanjutan dapat dilakukan untuk mempelajari hubungan antara nilai IGS3-60 dengan outcome gizi dan kesehatan.

\section{DAFTAR PUSTAKA}

Anwar K. 2013. Konsumsi Pangan dan Gizi serta Pola Pangan Harapan (PPH) pada Dewasa Usia 1949 Tahun di Indonesia. [Skripsi]. Departemen Gizi Masyarakat, Fakultas Ekologi Manusia, IPB, Bogor.

Apriani S \& Baliwati YF. 2011. Faktor-faktor yang berpengaruh terhadap konsumsi pangan sumber karbohidrat di perdesaan dan perkotaan. Jurnal Gizi dan Pangan, 6(3), 200-207.

Courtenay WH. 2003. Constructions of masculinity and their influence on men's well being: a theory of gender and health. Social Science and Medicine Journal, 50, 1385-1401.

Gibson RS. 20055. Principles of Nutritional Assessment $2^{\text {nd }}$ ed. Oxford University Press, New York.

Guenther PM, Reedy J, \& Krebs-Smith SM. 2008 Development of the healthy eating index. J Am Diet Assoc, 108, 1896-1901.

Guenther PM, Reedy J, Krebs-Smith SM, \& Reeve BB. 2008. Evaluation of the healthy eating index2005. J Am Diet Assoc, 108(11), 1854-1864.
Handayati SP, Nasoetion A, \& Sukandar D. 2008. Konversi satuan ukuran rumah tangga ke dalam satuan berat (gram) pada beberapa jenis pangan sumber protein. Jurnal Gizi dan Pangan, 3(1), 49-60.

Hardinsyah, Damayanthi E, \& Zulianti W. 2008. Hubungan konsumsi susu dan kalsium dengan densitas tulang dan tinggi badan remaja. Jurnal Gizi dan Pangan, 3(1), 43-48.

He FJ, Nowson CA, Lucas M, \& MacGregor GA. 2007. Increased consumption of fruit and vegetables is related to a reduced risk of coronary heart disease: meta analysis of cohort studies. Journal of Human Hypertension, 21, 717-728.

Henry FJ. 2011. Obesity prevention: The key to noncomunicable disease control. West Indian Med J, 60(4), 446-451.

Khatib 0. 2004. Non-communicable diseases: risk factors and regional strategies for prevention and care. Eastern Mediterranean Health Journal, 10(6), 778-788.

Lawlor DA, Ebrahim S, \& Smith GD. 2003. Sex matters: Secular and geographical trends in differences in coronary heart disease mortality. BMJ, 323, 541.

Lock K, Pomerleau J, Causer L, Altmann DR, \& MCkee Martin. 2005. The global burden of disease attributable to low consumption of fruit and vegetables: implication for the global strategy on diet. Bull World Health Organ, 83(2).

Nurhayati. 2013. Penentuan Jumlah dan Jenis Anjuran Konsumsi Sayur dan Buah Penduduk Indonesia menurut Kelompok Umur dan Jenis Kelamin. [Disertasi]. FKM, Universitas Indonesia, Depok.

Riboli E \& Norat T. 2003. Epidemiologic evidence of the protective effect of fruit and vegetables on cancer risk. Am J Clin Nutr, 78(3), 55955695.

Sugianti E, Hardinsyah, \& Afriansyah N. 2009. Faktor risiko obesitas sentral pada orang dewasa di DKI Jakarta: Analisis lanjut data Riskesdas 2007. Gizi Indon, 32(2), 105-116.

Taechangam S, Pinitchun, \& Pachotikarn C. 2008. Development of nutrition education tool: healthy eating index in Thailand. Asia Pac J Clin Nutr, 17(S1), 365-567. 